\title{
Winter abundance and distribution of Euphausia superba, E. crystallorophias, and Thysanoessa macrura in Gerlache Strait and Crystal Sound, Antarctica
}

\author{
Walter Nordhausen \\ Scripps Institution of Oceanography, La Jolla, California 92093-0202, USA
}

\begin{abstract}
Euphausia superba and Thysanoessa macrura were the 2 most abundant euphausiids in the ice-covered waters west of the Antarctic Peninsula duning July and August 1992. E. crystallorophias was limited to inshore waters. Detailed stratified sampling revealed that $E$. superba formed dense aggregations well below the ice, but was not inhabiting the ice itself. In general, E. superba occupied the depth stratum from 15 to $130 \mathrm{~m}$; few or no other zooplankton were found within $E$. superba swarms. T. macrura displayed a depth preference for the strata from 90 to $250 \mathrm{~m}$. Size-frequency distributions for $E$. superba and for $T$. macrura showed that larvae were absent and that both populations were dominated by small adults. A life cycle for T. macrura is proposed.
\end{abstract}

KEY WORDS: Euphausia superba - Euphausia crystallorophias . Thysanoessa macrura A Antarctic winter $\cdot$ Vertical and horizontal distribution - Size-frequency $\cdot$ Life cycle

\section{INTRODUCTION}

The Antarctic winter is a critical period in the life cycle of zooplankton. Long nights, and the prevalent ice cover which further decreases the total light available for phytoplankton, severely reduce primary production. Antarctic species are adapted physiologically and behaviorally to the extreme seasonality of the Southern Ocean. Because winter research in Antarctica has until recently been complicated by logistical difficulties and is restricted by its comparative expense, data about the distribution patterns of even the most prominent zooplankton species are scarce.

Antarctic krill Euphausia superba Dana is possibly the most abundant animal of its size on earth (Washburn \& Wooster 1981), and has long been the euphausiid species most studied in the Southern Ocean. Its important role in the Antarctic marine food chain, commercial value, and unique biology have justified numerous studies which have included investigations focused on its distribution and abundance (Hempel \& Marschoff 1980, Hempel 1981, Nast 1982,
Brinton 1985, Kittel et al. 1985, Piatkowski 1985, Daly \& Macaulay 1988) and their interannual variations (Brinton et al. 1987, Loeb et al. 1993); development rates (McClatchie 1988, Huntley \& Brinton 1991); age structure (Ettershank 1983, Brinton 1985); and physiological activities such as feeding (Kato et al. 1982, Segawa et al. 1982, Holm-Hansen \& Huntley 1984, Morris \& Priddle 1984), respiration, and excretion of ammonia and phosphate (Ikeda \& Mitchell 1982, Ikeda \& Bruce 1986, Ikeda \& Kirkwood 1989). Comparatively few studies have included other euphausiids (Makarov 1979, Kittel \& Stepnik 1983, Kittel et al. 1985, Pires 1986, Brinton \& Townsend 1991), although Thysanoessa macrura and E. crystallorophias have both been reported to outnumber $E$. superba in some areas (Brinton 1991, Hosie 1991. Nordhausen 1992).

Most studies on euphausiids have been conducted during the austral spring and summer, and a few during the fall. It is not surprising then that the biology and ecology of Euphausia superba is better understood for the period from October through April. However, very little is known about its biology and ecology dur- 
ing winter. The few existing winter studies have given rise to hypotheses that sometimes conflict. For examobscure. This euphausiid is known not to accumulate lipids as energy reserves for winter as Thysanoessa macrura does (Clarke 1984, Hagen 1988), and diapause by $E$. superba has never been reported even for periods when phytoplankton, the primary summer diet of krill, become almost undetectable in the water column. Recent studies indicate that krill can feed on icealgae on the underside of pack-ice in the Weddell Sea (Marschall 1988), Bransfield Strait (Gúzman 1983, Stretch et al. 1988), Scotia Weddell Sea (Daly 1990), and in the Indian Ocean north of Enderby Land (O'Brien 1987). Benthic feeding on detritus during the winter in shallow Lützow-Holm Bay has also been shrinkage during consecutive molts has been observed in long-term (Ikeda \& Dixon 1982) and short term (less than 1 molt cycle) (Nicol et al. 1992) laboratory experiments with starved krill. Quetin \& Ross (1991) proposed reduced metabolism in combination with starvation-induced body shrinkage as the overall wintering strategy of $E$. superba. However, remains of small crustaceans (e.g. copepods) have been found in the guts of krill during summer (Hopkins 1985) and fall (Hopkins \& Torres 1989), and krill consumption of copepods has ple, the overwintering strategy of $E$. superba is observed (Kawaguchi et al. 1986). Regressive body

been demonstrated in laboratory experiments conducted in the summer (Price et al. 1988) as well as in winter (Nordhausen et al. 1992, Huntley et al. 1994)

One principal goal of the RACER IV (Research on Antarctic Coastal Ecosystem Rates IV) expedition in austral winter 1992 was to investigate the distribution and activity of the common euphausiid species Euphausia superba, E. crystallorophias, and Thysanoessa macrura in the ice-covered waters west of the Antarctic Peninsula.

\section{MATERIALS AND METHODS}

Zooplankton sampling. The RACER program was a series of ship-based studies conducted from 1986 to 1993. This paper discusses results from RACER IV, which studied a $4000 \mathrm{~km}^{2}$ grid of 29 stations including previously surveyed Gerlache Strait and 6 additional stations (hereafter referred to as 'ice stations') along a transect from Anvers Island to Crystal Sound (Fig. 1). The sampling grid was occupied by the RV 'Nathaniel B. Palmer' from July 10 through August 15, 1992. The survey in Gerlache Strait took approximately $7 \mathrm{~d}$ to complete. Each of the 6 'ice stations' was occupied for $30 \mathrm{~h}$.

Zooplankton sampling was conducted, weather and ice conditions permitting, at all stations. A Multiple Opening Closing Net and Environ-

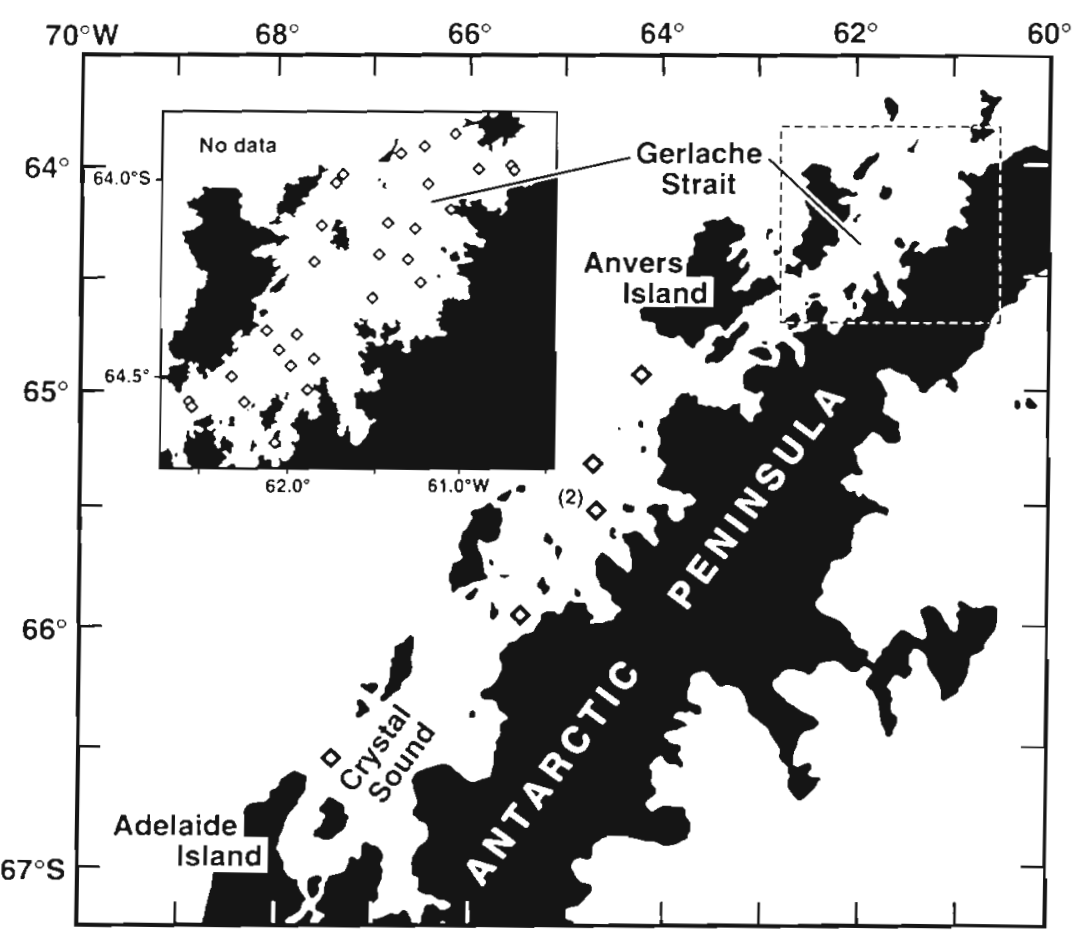

Fig. 1. Study area west of the Antarctic Peninsula, showing stations where MOCNESS tows were taken during July and August 1992. Inset shows locations of 29 sampling stations; locations of the 6 ice stations are shown in the main map portion; ' $(2)$ ' indicates where 2 ice stations were co-located mental Sensing System (MOCNESS; Wiebe et al. 1976), equipped with $333 \mu \mathrm{m}$ NITEX mesh nets, was deployed at depth intervals that had been designed to be consistent during the entire RACER program. The nets used in this study fished upward in the depth intervals 290-250, 250-210, $210-170,170-130,130-90,90-50$, 50-15, and 15-0 m. Each of the upward-fishing nets filtered approximately $150 \mathrm{~m}^{3}$ water, a volume generally sufficient to catch a number of zooplankton that was large enough for statistical purposes and yet still allow the analysis of the whole sample. Ship speed was kept between 2 and 2.5 knots. The research vessel's large size created an ice-free area behind the ship which permitted net tows even in $100 \%$ ice cover. At some stations net tows were performed in a previously broken channel. Additionally, Acoustic Doppler Current Profiler (ADCP) data were collected during MOCNESS tows and when steaming between stations (Zhou et al. in press). 
All zooplankton samples were preserved in boratebuffered $5 \%$ formaldehyde solution and later analyzed at the Scripps Institution of Oceanography.

Sample analyses. All euphausiids were identified and enumerated as previously described (Nordhausen 1992). Animals were classified according to stage; the term 'juveniles' is used for post-larval organisms in which the petasma or thelycum was not yet evident, and 'adults' are defined here as post-larval euphausiids for which sex could be determined by external morphology. If fewer than approximately 300 euphausiids were present in a sample, the entire sample was analyzed. The few larger samples were divided using a Folsom plankton-splitter and the appropriate corrections made.

Abundances were calculated based on flow-meter readings using standard equations (Wiebe et al. 1976). For most analyses the number of individuals per $\mathrm{m}^{2}$ integrated over the entire depth sampled (0 to $290 \mathrm{~m}$ ) was calculated from:

$$
N_{S}=\sum \frac{b_{i} Z_{i}}{V_{i}}
$$

where $N_{S}$ is the number of euphausiids per $\mathrm{m}^{2}$ at station $S, b_{i}$ the number caught in depth interval $i, v_{1}$ the volume filtered $\left(\mathrm{m}^{3}\right)$ in depth interval $i$, and $Z_{t}$ the thickness of depth interval $i(\mathrm{~m})$.

\section{RESULTS}

\section{Hydrography}

During July and August 1992, the northern and eastern parts of Gerlache Strait were covered by solid pack-ice with numerous large embedded icebergs. Pack-ice thickness was estimated to be between 0.5 and $1.0 \mathrm{~m}$. Solid fast-ice covered the coastal bays in southern Gerlache Strait. Occasional leads and some smaller areas of less compressed pack-ice were found at some of the stations in northwestern Gerlache Strait. To the south of Gerlache Strait, ice cover was solid and nearly always consisted of $100 \%$ fast-ice, with some occasional compressed pack-ice. Few small leads were found in the increasingly thick fast-ice south of Anvers Island and Crystal Sound. Fast-ice was up to $1.5 \mathrm{~m}$ thick, usually with an additional 0.2 to $0.3 \mathrm{~m}$ of snow cover.

Chlorophyll a (chl a) concentrations in the surface water column were at least 2 orders of magnitude lower than in summer (Holm-Hansen \& Vernet 1990), with highest values between

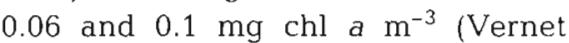

unpubl. data). The sea-ice throughout the area was white, rather than green as has been observed elsewhere, and ice cores taken revealed low chl a concentrations (W. Cochlan pers. comm.).

\section{Abundance and horizontal distribution}

Four euphausiid species - Euphausia superba, E. crystallorophias, E. triacantha, and Thysanoessa macrura - were found in July and August of 1992. Abundance data of all stages found (i.e. juveniles and adults; no larvae were found) for E. superba, E. crystallorophias, and T. macrura are presented in Table 1. The abundances of $E$. superba and $T$. macrura at the ice stations are shown in Table 2 . The contour graphs (Fig. 2) were generated with a commercially available program (SURFER 4.12; Golden Software, Inc.), which uses the kriging method to interpolate between stations. Neither of the 2 most common euphausiid species, E. superba and T. macrura, dominated the entire Gerlache Strait (Fig. 2); one or the other was more abundant at most stations. T. macrura and E. superba

Table 1 Euphausia superba, E. crystallorophias and Thysanoessa macrura. Statistics on abundance (ind. $\mathrm{m}^{-2}, 0$ to $290 \mathrm{~m}$ depth) of all individuals collected (adults and juveniles; no larval stages were found) from all stations sampled during RACER IV in July and August 1992 in Gerlache Strait. n: no. of stations

\begin{tabular}{|c|c|c|c|c|}
\hline & E. superba & crystall. & T. macrura & Total \\
\hline $\mathrm{n}$ & 35 & 35 & 35 & 35 \\
\hline Minimum & 0 & 0 & 0 & 1 \\
\hline Maximum & 810 & 83 & 92 & 868 \\
\hline Mean & 89 & 6 & 38 & 133 \\
\hline SE & 152 & 15 & 29 & 27 \\
\hline Variance & 232273 & 216 & 819 & 25844 \\
\hline Skewness ${ }^{a}$ & 3.33 & 4.38 & 0.37 & 3.03 \\
\hline Kurtosis ${ }^{b}$ & 12.59 & 20.29 & -0.96 & 10.78 \\
\hline
\end{tabular}

Table 2. Euphausia superba and Thysanoessa macrura. Individual and total abundances at the ice stations (ind. $\mathrm{m}^{-2}$, integrated from 0 to $290 \mathrm{~m}$ )

\begin{tabular}{|cccccc|}
\hline Station & Latitude & Longitude & E. superba & T. macrura & Total \\
\hline IC1 & $65.536^{\circ} \mathrm{S}$ & $64.678^{\circ} \mathrm{W}$ & 140.5 & 3.0 & 143.5 \\
IC2 & $65.536^{\circ} \mathrm{S}$ & $64.678^{\circ} \mathrm{W}$ & 18.2 & 91.9 & 110.1 \\
IC3 & $66.596^{\circ} \mathrm{S}$ & $67.490^{\circ} \mathrm{W}$ & 40.6 & 50.9 & 91.5 \\
IC4 & $65.977^{\circ} \mathrm{S}$ & $65.423^{\circ} \mathrm{W}$ & 3.1 & 77.2 & 80.3 \\
IC5 & $65.335^{\circ} \mathrm{S}$ & $64.698^{\circ} \mathrm{W}$ & 22.3 & 40.5 & 62.8 \\
IC6 & $64.933^{\circ} \mathrm{S}$ & $64.294^{\circ} \mathrm{W}$ & 0.5 & 50.7 & 51.2 \\
\hline
\end{tabular}


E. superba

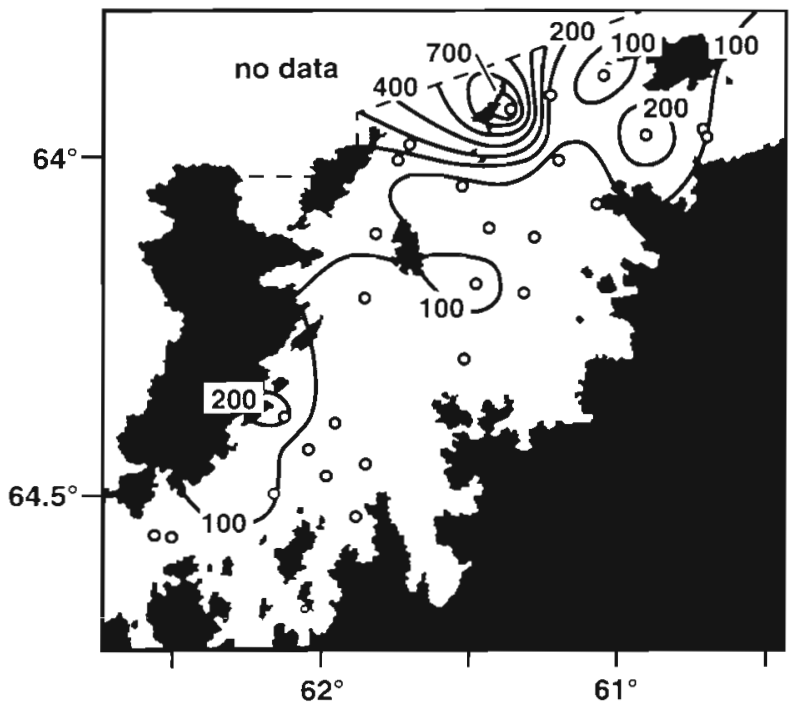

Thysanoessa macrura

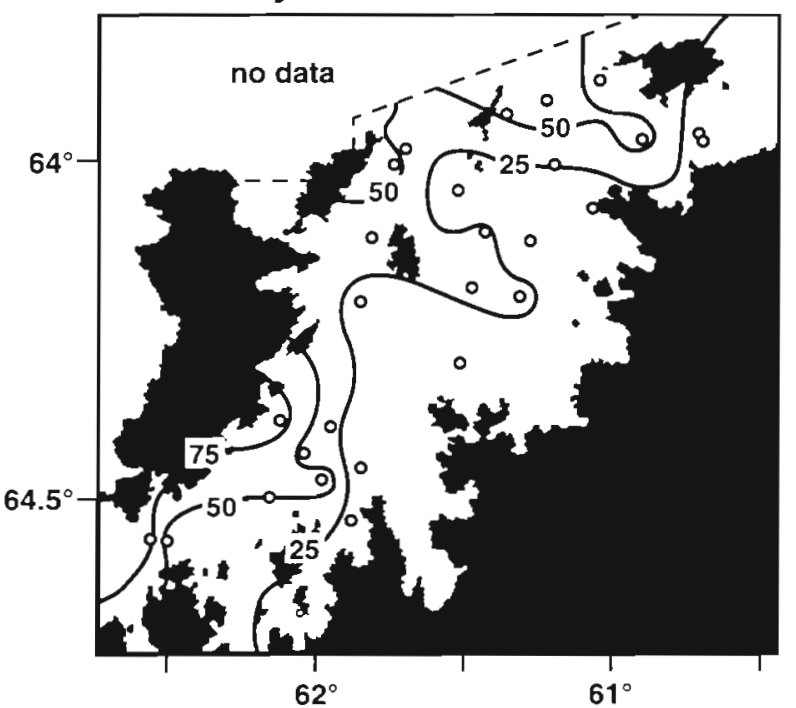

E. crystallorophias

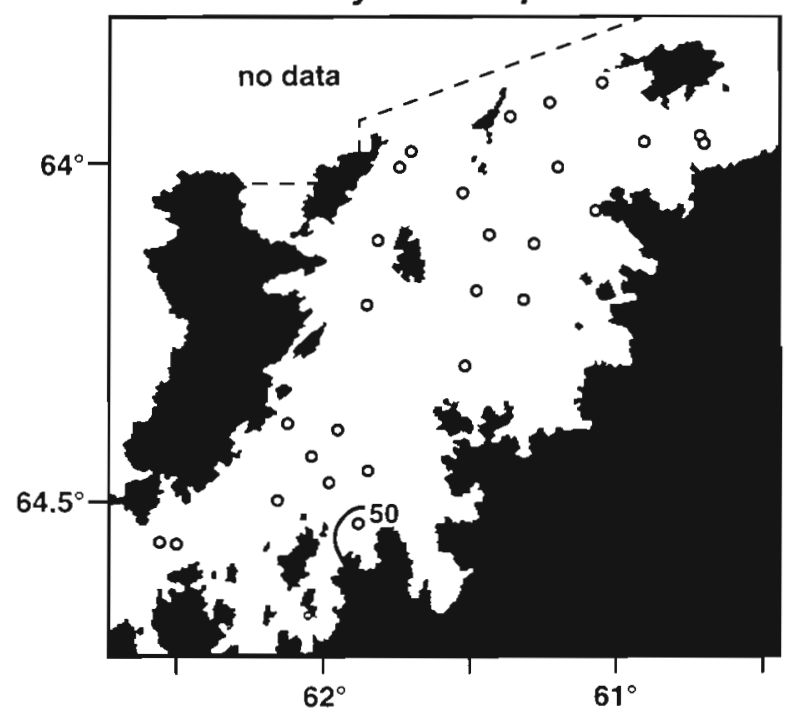

all three species

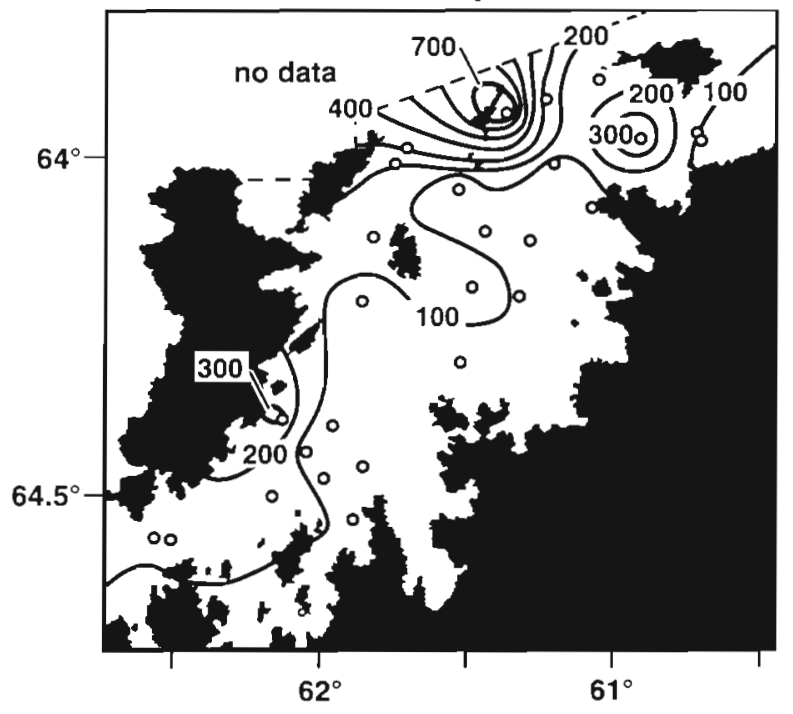

Fig. 2. Euphausia superba, E. crystallorophias and Thysanoessa macrura. Distribution of each species, and of all 3 species combined, for all stages in Gerlache Strait during July 1992. Abundance data are given as ind. $\mathrm{m}^{-2}$, integrated from 0 to $290 \mathrm{~m}$ depth. Circles indicate station locations

were found at all but 1 of 35 stations. E. superba was most abundant overall, with the highest observed abundance of 810 ind. $\mathrm{m}^{-2}$ found at one station in northern Gerlache Strait. The greatest abundance of $T$. macrura was lower (91 ind. $\mathrm{m}^{-2}$ ). The distributions of $E$. superba and T. macrura were very similar (Fig. 2). Both species had higher abundances in northern and western Gerlache Strait. E. crystallorophias was, on average, less abundant than E. superba and T. macrura, and was absent at 8 of the 35 stations sampled, but was the most numerous species at some coastal stations (Fig, 2). A total of only 4 adult $E$. triacantha were found at 2 of the ice-stations, and for this reason this species is not discussed further.

Numerous strong echo-returns from large (hundreds of meters in extent) targets in the upper $100 \mathrm{~m}$ of the water column were detected by the ADCP surveys conducted throughout the study area. MOCNESS samples intentionally collected from these acoustical targets consisted almost exclusively of Euphausia superba (Zhou et al. in press). An attempt was made to compare the distribution patterns of the 3 common euphausiid species. The normalized mean abundance per station for each of the 3 euphausiid species (ind. 


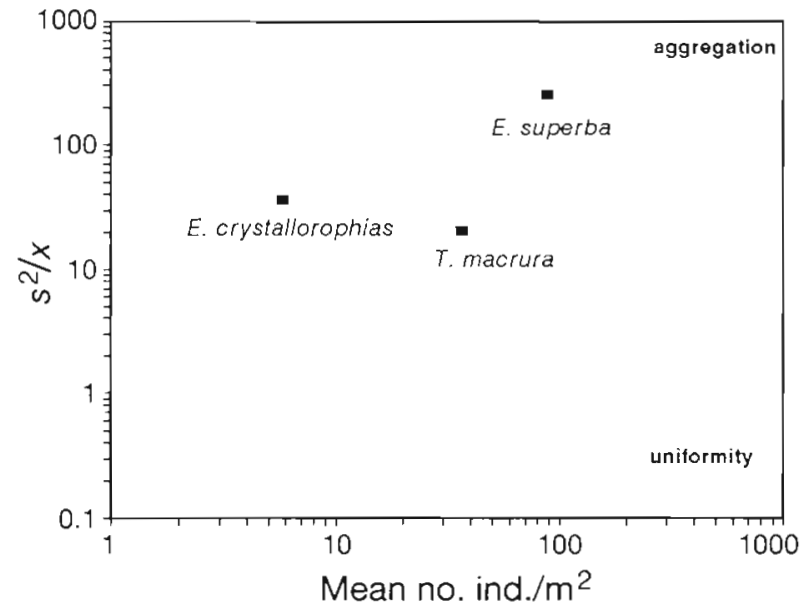

Fig. 3. Euphausia superba, E. crystallorophias and Thysanoessa macrura. Valiela's index of aggregation (see text). $s^{2}$ : variance; $x$ : mean

$\mathrm{m}^{-2}$ ) is plotted in Fig. 3 against Valiela's (1984) index of aggregation (variance/mean). Use of this index is not intended to imply probabilities since by necessity normalized data are used here. The volume filtered per net was intended to be $150 \mathrm{~m}^{3}$ but varied from 100 to $200 \mathrm{~m}^{3}$. However, this index is useful for showing the relative species-specific distribution patterns: the distribution of $E$. superba is most aggregated, that of Thysanoessa macrura most uniform, and that of $E$. crystallorophias intermediate.

Because of the short daylight period ( $7 \mathrm{~h}$ ) during the survey, most net tows were conducted at night. Euphausia crystallorophias and Thysanoessa macrura showed no statistically significant difference in abundance for samples collected during the daylight versus dark period (Mann-Whitney $U$-test). However, abundances of $E$. superba were significantly lower in daylight samples than in those taken at night (Mann-Whitney $U$-test, $p<0.001$ ), suggesting net avoidance since diel vertical migration was not observed (see following section). For this reason only samples collected during the night were used in the analyses of size-frequency and vertical distribution of E. superba, in order to minimize possible effects of net avoidance, particularly by larger specimens.

\section{Vertical distribution}

Under-ice video camera observations throughout the area using a remotely operated vehicle (ROV) revealed the absence both of ice discoloration due to microalgae and of euphausiids directly under the ice. Additionally, discolored ice was not observed in the ship's wake. The absence of ice algae did not completely preclude the presence of krill under the ice, however. Our shipmounted (downward looking) ADCP did not sample the stratum $0-15 \mathrm{~m}$, and thus could not provide any data for krill abundance directly under the ice, nor was it possible to sample directly under the ice with the MOCNESS.

The ROV was therefore used for direct under-ice observations, but no krill were found under the ice. MOCNESS data are thus not biased by our not having sampled krill associated with ice. Euphausia superba was most often collected by the MOCNESS in the stratum 15-50 m. Thysanoessa macrura and E. crystallorophias were found at greater depths.

Fig. 4 shows the vertical distribution pattern of each species plotted for individual stations. Each of the 3 euphausiid species displayed a consistent pattern in its vertical distribution and no vertical migration was observed when the depth of the center of mass (Vinogadrov 1970) was plotted against time of day (data not shown). The distribution maximum of Euphausia superba was generally at about $30 \mathrm{~m}$ depth, although this species also frequently occurred between 50 and $150 \mathrm{~m}$. Thysanoessa macrura occurred primarily between 120 and $220 \mathrm{~m}$ with a mean distribution maximum at $190 \mathrm{~m}$. Interestingly, T. macrura was strikingly scarce at depths above $50 \mathrm{~m}$, the stratum occupied by the majority of E. superba caught. E. crystallorophias did not show a clear preference for any depth. The vertical distribution profile of all 3 species combined was dominated by E. superba because of the high abundances of this species throughout most of the study area, with the maximum found at $30 \mathrm{~m}$ and a smaller secondary peak, attributable to $T$. macrura, at around $200 \mathrm{~m}$ depth.

The size-frequency distribution of Euphausia superba by depth stratum is presented in Fig. 5, and mean body length per stratum given in Table 3 . At stations where swarms of E. superba were found, all other zooplankton were scarce or absent in the depth strata that it occupied. At these stations, a distinct stratification of individuals according to body size was evident, with smaller animals (18 to $35 \mathrm{~mm}$ ) found mostly above $130 \mathrm{~m}$ and larger individuals ( 36 to $55 \mathrm{~mm}$ ) below $130 \mathrm{~m}$ (Fig. 5). Few E. superba were found below $210 \mathrm{~m}$ depth.

\section{Size-frequency distribution}

The size-frequency distributions for the 3 species are shown in Fig. 6. The data for Thysanoessa macrura and for Euphausia crystallorophias are from all samples collected in Gerlache Strait and along the transect through the Grandidier Channel to Crystal Sound. The corresponding data for E. superba are taken only from samples collected at night, in order to minimize possible effects of net avoidance (particularly by larger specimens). 
For Euphausia superba, body lengths of 25 to $26 \mathrm{~mm}$ predominated, but all sizes between 20 and $30 \mathrm{~mm}$ were commonly found. No larvae or small juveniles were caught, and larger adults up to $50 \mathrm{~mm}$ occurred. Most male E. superba were larger than $35 \mathrm{~mm}$. No significant difference in mean length was detected in a comparison of samples collected during day and night (Mann-Whitney $U$-test).

The size-frequency distribution of Thysanoessa macrura was clearly unimodal and peaked at $14 \mathrm{~mm}$. Larvae were absent and very few juveniles smaller than $13 \mathrm{~mm}$ were found.

The size-frequency distribution of Euphausia crystallorophias differed strikingly from that of $E$. superba and Thysanoessa macrura. Late larval stages of 8 and $9 \mathrm{~mm}$ length predominated, although adults of 20 to $31 \mathrm{~mm}$ body length were found.

\section{Comparison of summer and winter distribution of Euphausia superba}

High abundances of Euphausia superba were found in the northern part of Gerlache Strait in summer (Brinton in press) as well as in winter (this study). Comparison of the sizefrequency distributions from Brinton's (unpubl.) December/January 1991 data to those from July/August 1992 revealed striking similarities in the shape of the 2 distributions (Fig. 7). Both display at least 2 relative distribution maxima of adult E. superba of $<30 \mathrm{~mm}$ body length: these were at 21 and $24 \mathrm{~mm}$ body length in December/January, and at 24 and $27 \mathrm{~mm}$ in July/August.

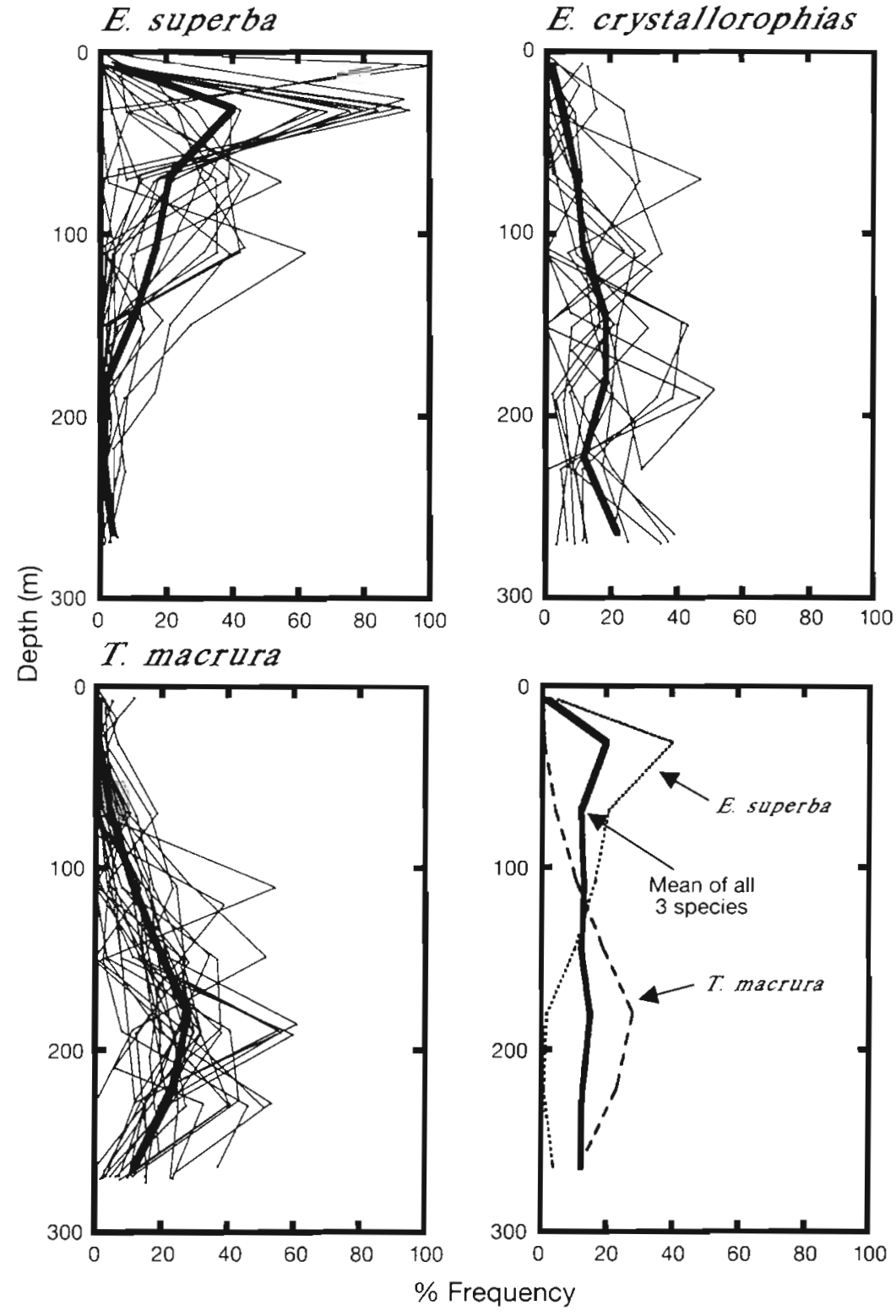

Fig. 4. Euphausia superba, E. crystallorophias and Thysanoessa macrura. Vertical distribution of abundances expressed as percent of the total. In the graphs for each species, the thin lines represent actual measurements and the thick line the mean of each individual species. The bottom right graph shows the mean distribution of the dominant species E. superba and T. macrura and of all 3 species combined

\section{DISCUSSION}

\section{Horizontal distribution}

These results are from one of the few Antarctic sampling programs ever conducted in the solid pack-and fast-ice of the austral winter. Krill in pack-ice have been observed from ships since the turn of the century (Marr 1962), but vertical net tows and echo sounders have failed in the past to locate large krill stocks during winter in ice-free (Heygood et al. 1985) or ice-covered areas (Marr 1962, Gúzman 1983, Stepien 1983). More recent observations by SCUBA divers and video-equipped ROVs have provided direct evidence for the presence of Antarctic krill under sea ice (O'Brien 1987. Marschall 1988, Stretch et al. 1988, Daly 1990).

During the present investigation, all 3 common species of Antarctic euphausiids - Euphausia superba, E. 

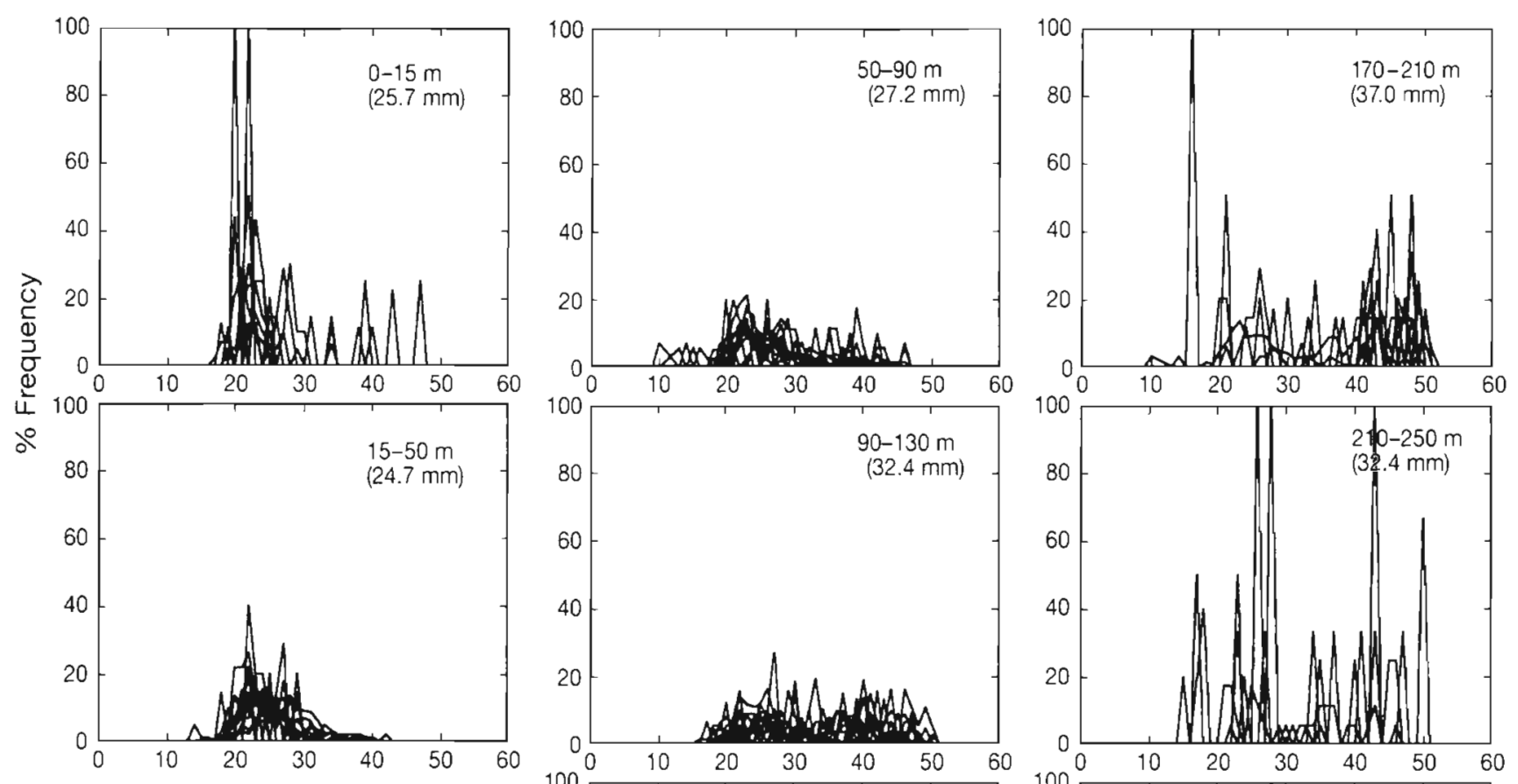

Fig. 5. Euphausia superba. Relative sizefrequency $(\%)$ distribution in 8 depth strata between the surface and the maximum depth sampled $(290 \mathrm{~m})$. Data are from stations at which $E$. superba was especially abundant $(6,25,26,28,42,43,44)$
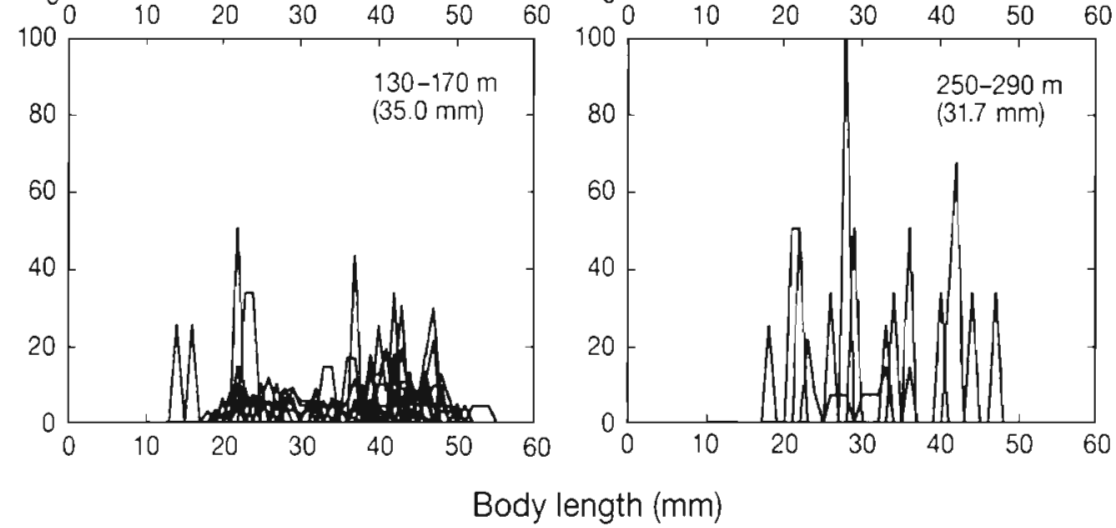

crystallorophias, and Thysanoessa macrura -- were present throughout the study area west of the Antarctic Peninsula in July and August 1992. The distribution of $E$. superba was similar to that observed in December 1991 and January 1992 (Brinton pers. comm.). It was the most abundant euphausiid overall during this winter study, with a mean abundance higher by a factor of 2 than that of the next most common euphausiid, $T$. macrura. The catch of $E$. superba was characterized by the complete absence of larval stages, and was composed primarily of small sub-adults. The swarming behavior observed during the present investigation by continuous ADCP measurements (Zhou et al. in press) was supported by the MOCNESS catches directed at strong acoustic returns: concentrations as high as 810 ind. $\mathrm{m}^{-2}$ were found in one large swarm.

Although reported as early as 1908 to be the euphausiid species second in dominance to Euphausia superba (Tattersall 1908, Rustad 1930), Thysanoessa macrura has received little attention. The present sur- vey gives the first detailed description of $T$. macrura's winter abundance, spatial distribution, and size-frequency distribution under solid ice in the region of the Antarctic Peninsula. T. macrura was the most uniformly distributed euphausiid throughout Gerlache Strait, the Grandidier Channel, and Crystal Sound. The mean abundance found during this winter study was 39 ind. $\mathrm{m}^{-2}$, roughly half the number observed in the same study area in summer (84.1 ind. $\mathrm{m}^{-2}$ in November 1989; Nordhausen in press). However, the spring/summer population in the same region had been dominated by larval stages (82.5\% of the total) (Nordhausen in press), in strong contrast to the winter catch, which was composed entirely of post-larval individuals, most of which were adults larger than $12 \mathrm{~mm}$. A greater overall number of post-larval stages was therefore present during the winter than in summer. The relatively high winter abundances of $T$. macrura reported here for Gerlache Strait differ markedly from the low numbers $(0.55$ ind. $\mathrm{m}^{-2}$ integrated over 0 to $200 \mathrm{~m}$ ) observed for oceanic 

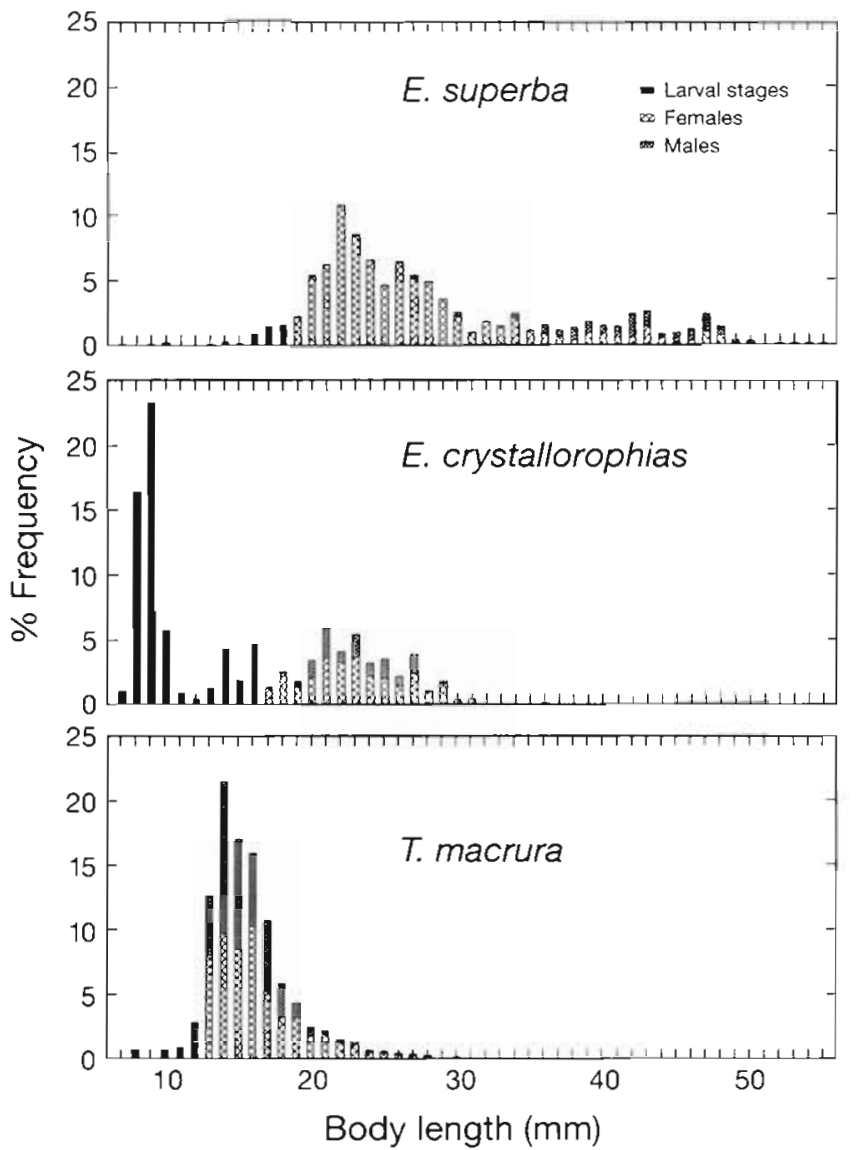

Fig. 6. Euphausia superba, E. crystallorophias, and Thysanoessa macrura. Relative size-frequency (\%) distribution

communities at the Weddell-Scotia Confluence during winter 1988 (Lancraft et al. 1991) .

Euphausia crystallorophias was almost always collected in small numbers, at inshore stations near the Antarctic Peninsula, with a maximum catch of 81 ind. $\mathrm{m}^{-2}$. This generally neritic distribution and occasional high abundance accords with other published reports (Rakuza-Suszczewski \& Stepnik 1980, Siegel 1987. Brinton 1991).

\section{Vertical distribution}

Reports on net avoidance by euphausids are not always consistent (Bone 1986), but it appears that larger species and older stages are more likely to escape approaching nets due to their greater mobility (Mathew 1988). Euphausia superba has previously been reported to avoid moving objects, including nets, by visual cues (Marr 1962). In the present study, net avoidance was observed for $E$. superba but not for $E$. crystallorophias and Thysanoessa macrura when abundance data from day and night were compared.

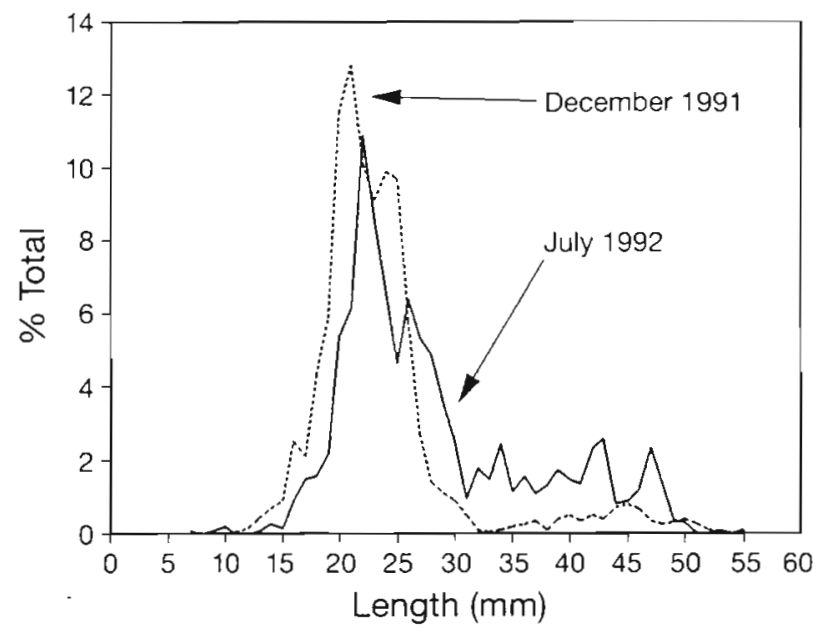

Fig. 7. Euphausia superba. Size-frequency (\%) distribution during summer (December-January 1991-92) and winter (July-August 1992) in Gerlache Strait. Data are means of samples collected from 18 stations in summer (Brinton in press) and 35 stations in winter

Therefore, for E. superba, only night samples were used in the analysis of vertical distribution and sizefrequency, in order to alleviate statistical bias due to visual avoidance (Witek et al. 1985, Ohman 1986).

Underwater video observations conducted during this study revealed the absence of krill directly under icefloes or in ice-channels, in complete contrast to observations by Marschall (1988) during winter 1986 in the Weddell Sea. However, this absence of krill directly under the ice was not surprising since 'green' or 'brown' ice containing microalgae (on which the krill have been observed to feed; Marschall 1988, Stretch et al. 1988) was not found in this study area. Similar findings were reported by Daly (1990) from observations by divers in the Scotia Sea, where 'in areas [under the ice] without noticeable concentrations of ice algae, krill densities were $\sim 1$ individuals $\mathrm{m}^{-2}$, while densities up to 28,600 individuals $\mathrm{m}^{-3}$ were concentrated in small crevasses containing ice algae'. Krill was rarely associated with ice that did not appear to support sea ice biota (Daly 1990).

In contrast, Euphausia superba was common in the water column, occurring in dense aggregations detected by both MOCNESS tows and ADCP measurements (Zhou et al. in press). Highest abundances of $E$. superba were found in the upper $100 \mathrm{~m}$, in agreement with summer observations in the Weddell Sea by Siegel et al. (1990), who found that $98 \%$ of krill caught by rectangular midwater trawl were in the upper $200 \mathrm{~m}$ with 60 to $99 \%$ in the $0-60 \mathrm{~m}$ stratum. Similar results were found by Daly \& Macaulay (1988) during austral spring 1983 near the ice edge in northwestern Weddell Sea, where $96 \%$ of E. superba swarms occurred in the upper $100 \mathrm{~m}$ and $81 \%$ in the upper 
$50 \mathrm{~m}$. Miller et al. (1993) analyzed the distributional features of $4830 \mathrm{E}$. superba aggregations detected acoustically in the Atlantic sector of the Southern Ocean and found the mean depth of these aggregations to be $36.2 \mathrm{~m}$ (range $=0$ to $89.0 \mathrm{~m}$ ).

\section{Life cycle considering winter observations}

The 3 euphausiid species discussed here have geographically overlapping distributions. Although all are euphausiids, great differences in their ecology are apparent. Euphausia superba is the largest species (<70 mm) (Dzik \& Jazdzewski 1978). It has generally been considered herbivorous (Mauchline \& Fisher 1969), which is unusual for euphausiids. Dense aggregations of krill, presumably exploiting the annual phytoplankton bloom, have been observed during the summer. Winter observations, though still limited, have led to proposals that krill undergo reduced metabolic rate or body shrinkage as overwintering strategies, with feeding on ice algae supplying limited addi-

Table 3. Euphausia superba, E. crystallorophias, and Thysanoessa macrura. Abundances (ind. $\mathrm{m}^{-3}$ ) from all stations sampled are considered. n: no. of stations

\begin{tabular}{|c|c|c|c|c|c|c|c|c|}
\hline & \multicolumn{8}{|c|}{ Depth stratum (m) } \\
\hline & $0-15$ & $15-50$ & $50-90$ & $90-130$ & $130-170$ & $170-210$ & $210-250$ & $250-290$ \\
\hline \multicolumn{9}{|c|}{ Euphausia superba } \\
\hline $\mathrm{n}$ & 35 & 35 & 35 & 35 & 35 & 35 & 35 & 35 \\
\hline Minimum & 0.0 & 0.0 & 0.0 & 0.0 & 0.0 & 0.0 & 0.0 & 0.0 \\
\hline Maximum & 8.70 & 20.1 & 2.43 & 3.59 & 1.83 & 1.69 & 0.55 & 1.99 \\
\hline Mean & 0.37 & 1.32 & 0.31 & 0.34 & 0.12 & 0.08 & 0.06 & 0.08 \\
\hline $\mathrm{SE}$ & 0.26 & 0.62 & 0.09 & 0.13 & 0.06 & 0.05 & 0.02 & 0.06 \\
\hline Variance & 2.76 & 13.4 & 0.29 & 0.60 & 0.11 & 0.90 & 0.02 & 0.11 \\
\hline Skewness $^{\mathrm{a}}$ & 5.10 & 4.20 & 2.62 & 2.97 & 4.18 & 4.82 & 2.71 & 5.37 \\
\hline Kurtosis $^{\mathrm{b}}$ & 25.3 & 18.3 & 6.7 & 8.3 & 17.9 & 23.0 & 6.3 & 27.8 \\
\hline \multicolumn{9}{|c|}{ Euphausia crystallorophias } \\
\hline $\mathrm{n}$ & 35 & 35 & 35 & 35 & 35 & 35 & 35 & 35 \\
\hline Minimum & 0.0 & 0.0 & 0.0 & 0.0 & 0.0 & 0.0 & 0.0 & 0.0 \\
\hline Maximum & 0.04 & 0.09 & 0.19 & 0.60 & 0.46 & 0.41 & 0.20 & 0.27 \\
\hline Mean & 0.003 & 0.007 & 0.015 & 0.026 & 0.028 & 0.023 & 0.018 & 0.025 \\
\hline $\mathrm{SE}$ & 0.001 & 0.003 & 0.07 & 0.017 & 0.014 & 0.012 & 0.007 & 0.009 \\
\hline Variance & 0.000 & 0.000 & 0.001 & 0.010 & 0.007 & 0.005 & 0.002 & 0.003 \\
\hline Skewness & 3.22 & 3.13 & 3.31 & 5.24 & 4.61 & 4.78 & 3.01 & 2.91 \\
\hline Kurtosis & 9.27 & 9.58 & 11.50 & 26.74 & 22.02 & 23.03 & 9.47 & 8.94 \\
\hline \multicolumn{9}{|c|}{ Thysanoessa macrura } \\
\hline$n$ & 35 & 35 & 35 & 35 & 35 & 35 & 35 & 35 \\
\hline Minimum & 0.0 & 0.0 & 0.0 & 0.0 & 0.0 & 0.0 & 0.0 & 0.0 \\
\hline Maximum & 0.66 & 0.40 & 1.71 & 0.52 & 0.44 & 1.18 & 0.92 & 0.71 \\
\hline Mean & 0.03 & 0.02 & 0.09 & 0.11 & 0.16 & 0.24 & 0.21 & 0.71 \\
\hline SE & 0.02 & 0.01 & 0.05 & 0.02 & 0.02 & 0.25 & 0.21 & 0.08 \\
\hline Variance & 0.01 & 0.05 & 0.08 & 0.02 & 0.02 & 0.07 & 0.05 & 0.02 \\
\hline Skewness & 5.35 & 4.83 & 5.24 & 1.37 & 0.36 & 1.89 & 1.46 & 3.28 \\
\hline Kurtosis & 25.3 & 18.3 & 6.7 & 8.3 & 17.9 & 23.0 & 6.3 & 27.8 \\
\hline \multicolumn{9}{|c|}{ Total for all 3 species } \\
\hline $\mathrm{n}$ & 35 & 35 & 35 & 35 & 35 & 35 & 35 & 35 \\
\hline Minimum & 0.0 & 0.0 & 0.0 & 0.0 & 0.0 & 0.0 & 0.0 & 0.0 \\
\hline Maximum & 9.36 & 20.1 & 2.57 & 3.96 & 2.16 & 2.08 & 1.04 & 2.12 \\
\hline Mean & 0.41 & 1.35 & 0.42 & 0.47 & 0.30 & 0.35 & 0.28 & 0.19 \\
\hline $\mathrm{SE}$ & 0.28 & 0.62 & 0.10 & 0.14 & 0.07 & 0.07 & 0.04 & 0.08 \\
\hline Variance & 2.68 & 13.4 & 0.36 & 0.64 & 0.15 & 0.17 & 0.07 & 0.14 \\
\hline Skewness & 5.07 & 4.20 & 2.13 & 3.02 & 3.32 & 2.54 & 1.33 & 4.38 \\
\hline Kurtosis & 24.9 & 18.3 & 4.03 & 9.37 & 13.59 & 12.2 & 9.82 & 6.47 \\
\hline
\end{tabular}


tional energy. However, recent studies have suggested carnivory during periods of low phytoplankton concentrations as a mechanism to avoid starvation and allow growth during winter (Huntley et al. 1994).

Thysanoessa macrura, a much smaller $(<31 \mathrm{~mm}$ ) species, has received less attention. Its life history is still being debated in spite of its wide distribution and frequently high abundance. It is considered to be omnivorous, and its lipid composition is typical for boreal euphausiids, viz. high concentrations of wax esters, which could not only serve as energy reserves for the winter, but also explain the early spawning before the development of a phytoplankton bloom.

Euphausia crystallorophias $(<37 \mathrm{~mm})$ is generally considered neritic, and can dominate the euphausiid population in coastal areas. Feeding on ice algae has been observed. Reproduction begins early in spring before the development of the spring bloom.

However, the part of the euphausiid life cycle that occurs during winter has been left subject to much speculation due to the paucity of data. The discussion that follows incorporates winter data from the present study into what is known about the life cycles of Euphausia superba and Thysanoessa macrura in Gerlache Strait. Because of the lack of better characters for estimating the age of euphausiids, body length data are used here to separate age groups and to estimate growth rates, as is commonly done (McClatchie 1988, Brinton 1991, Brinton \& Townsend 1991, Huntley \& Brinton 1991). However, the following caveats should be considered. Analysis of data from non-successive years can be misleading because of interannual variation and regional differences. For example, mesoscale variation of growth and early development rates possibly due to varying food availability - has been reported for E. superba (Huntley \& Brinton 1991), and body shrinkage of $E$. superba during periods of food limitation has been observed both in laboratory experiments (Ikeda \& Dixon 1982) and in the field (Quetin \& Ross 1991, Nicol et al. 1992).

Even though interannual variability cannot be ruled out, the observations made over the 6 yr duration of the entire RACER program were remarkably consistent, and a life cycle for Thysanoessa macrura can be proposed. Fig. 8 shows a schematic life cycle of T. macrura based on observed size-frequency distributions from field samples collected in 1986/87, 1989 and 1992. Early calyptopis stages were found in Gerlache Strait in November (1989) (Nordhausen in press). During this month, the proportion of females carrying spermatophores decreased (Nordhausen in press); as spermatophores are firmly attached to the thelycum of females and are probably not shed until the next molt (Mauchline 1980), spawning had probably begun prior to November. In December (1986), late calyptopis and

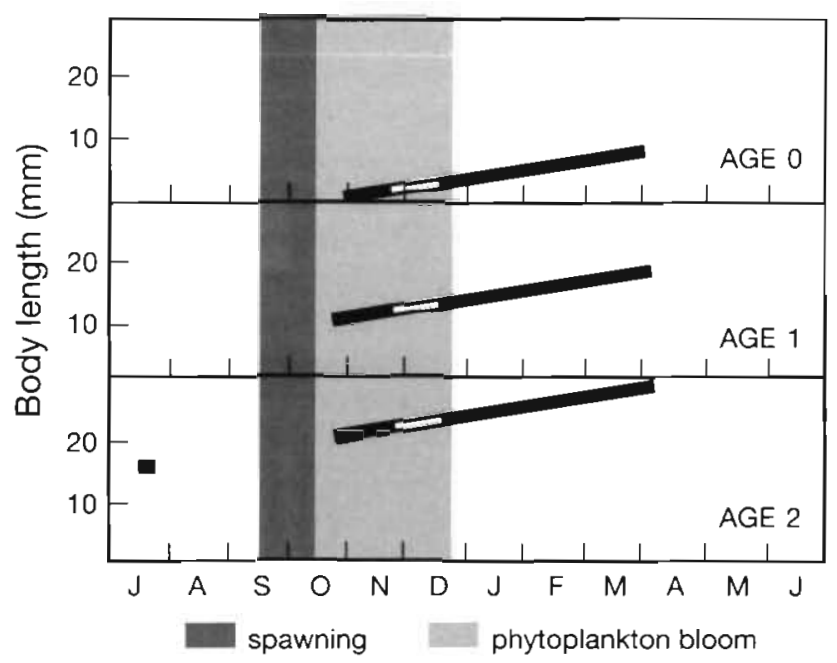

Fig. 8. Thysanoessa macrura. Schematic life cycle showing 3 age groups, based on size-frequency distributions from fieldcollected samples in 1986-87, 1989, and winter 1992 (black square in bottom graph). Shading indicates months in which T. macrura spawning and the annual phytoplankton bloom typically occur. The open (white) portion of the line in each graph indicates missing data

early furcilia stages were found, which developed to late furcilia and early juveniles with mean body lengths of $8.5 \mathrm{~mm}$ by the following March (Nordhausen 1992). In July/August (1992), the population consisted entirely of post-larval animals, mostly individuals, with unimodal maximum at $14 \mathrm{~mm}$ in the sizefrequency distribution. In November (1989), aside from the early calyptopes already mentioned, a mode consisting of adults 14 to $18 \mathrm{~mm}$ long was apparent. One interpretation of these observations made over several years is the following: (1) calyptopes grow to early juveniles in the period from November to the following March, (2) by winter of that year, individuals of this cohort have matured into adults, and (3) spawning begins at some point early in austral spring (September-October), and is participated in by females as small as $14 \mathrm{~mm}$ long, though most are larger.

The striking similarities in shape of the size-frequency distributions of E. superba sampled in January (Brinton in press) and in July/August 1992 (the present study) suggest that same population may have been sampled on both occasions. Assuming that this is the case, then the observed shift of the size-frequency distribution to greater body lengths indicates an overall increase of body length of about $2 \mathrm{~mm}$ between January and July 1992. Euphausia superba females were just beginning to spawn at the end of the RACER III survey in Gerlache Strait in January 1992 (Brinton pers. comm.). Calyptopis stages of E. superba were found in Gerlache Strait during January and February 1987 (Brinton 1991, Huntley 
\& Brinton 1991). The absence of larval E. superba in austral winter 1992 is possibly due to a recruitment failure in that year or to advection of larval stages out of Gerlache Strait (hydrographic observations of surface water movements support the latter possibility; Niiler et al. 1990). The question of whether the early adults that were observed in winter mature by the following spring and participate in the December/January spawning remains open.

Acknowledgements. I thank the participants of the RACER IV Winter Cruise, C. Dasco, V. Øresland, S. Beaulieu, J. Illeman and the Antarctic Support Associates, Inc. (ASA) personnel $H$. Owen and $H$. Baker for their help with the MOCNESS operations; M. Zhou for generously providing the software for the contour plots; E. Venrick for her expert assistance with the statistical analysis; and E. Brinton for sharing his data on $E$. superba's summer size-frequency distribution. I am especially grateful to M. Huntley, J. McGowan, D. DeMaster, E. Brinton, $M$. Unson, and 3 anonymous reviewers for their constructive criticism which greatly improved this manuscript. This research was supported by ONR grant \#NOO014-92-J-618 and by NSF grant DPP-89-17778 to M. Huntley.

\section{LITERATURE CITED}

Bone, D. G. (1986). An LHPR system for adult Antarctic krill (Euphausia superba). Br. Antarct. Surv. Bull. 73: 31-46

Brinton, E. (1985). The oceanic structure of the eastern Scotia Sea - III. Distributions of euphausiid species and their developmental stages in 1981 in relation to hydrography. Deep Sea Res. 32: 1153-1180

Brinton, E. (1991). Distribution and population structures of immature and adult Euphausia superba in the western Bransfield Strait region during the 1986-87 summer. Deep Sea Res. 38: 1169-1193

Brinton, E. (in press). RACER: Euphausia superba in Gerlache Strait, springs of 1989 and 1991. Antarctic J. U.S.

Brinton, E., Loeb, V. J., Macauly, M. C., Schulenberger, E. (1987). Variability of Euphausia superba populations near Elephant Island and the South Shetlands: 1981 vs. 1984. Polar Biol. 7: 345-362

Brinton, E., Townsend, A. (1991). Development rates and habitat shifts in the Antarctic neritic euphausiid Euphausia crystallorophias, 1986-87. Deep Sea Res. 38; $1195-1211$

Clarke, A. (1984). Lipid content and composition of Antarctic krill, Euphausia superba Dana. J. Crust. Biol. 4 (Spec. No. 1): $285-294$

Daly, K. L. (1990). Overwintering development, growth, and feeding of larval Euphausia superba in the Antarctic marginal ice zone. Limnol. Oceanogr. 35: 1564-1576

Daly, K. L., Macaulay, M. C. (1988). Abundance and distribution of krill in the ice edge zone of Weddell Sea, austral spring 1983. Deep Sea Res. 35: 21-41

Dzik, J., Jazdzewski, K. (1978). The euphausiid species of the Antarctic region. Pol. Arch. Hydrobiol. 25: 589-605

Ettershank, G. (1983). Age structure and cyclical annual size change in the Antarctic krill Euphausia superba Dana. Polar Biol. 3: 189-193

Gúzman, O. (1983). Distribution and abundance of Antarctic krill (Euphausia superba) in the Bransfield Strait. Ber Polarforsch. 4: 169-190
Hagen, W. (1988). Zur Bedeutung der Lipide im antarktischen Zooplankton. Ber. Polarforsch. 49: 1-129

Hempel, I. (1981). Euphausiid larvae in the Scotia Sea and adjacent waters in the summer 1977/78. Meeresforsch. 29: 53-59

Hempel, I., Marschoff, E. (1980). Euphausiid larvae in the Atlantic sector of the Southern Ocean. Meeresforsch. 28: $32-40$

Heygood, R. B., Everson, I., Priddle, J. (1985). The absence of krill from the Georgia zone, winter 1983. Deep Sea Res. 32: $369-378$

Holm-Hansen, O., Huntley, M. (1984). Feeding requirements of krill in relation to food sources. J. Crust. Biol. 4 (Spec. No. 1): 156-173

Holm-Hansen, O., Vernet, M. (1990). Phytoplankton distribution and rates of primary production during the austral spring bloom. Antarctic J. U.S. 25: 141-144

Hopkins, T. L. (1985). Food web of an Antarctic midwater ecosystem. Mar. Biol. 89: 197-212

Hopkins, T. L., Torres, J. J. (1989). Midwater food web in the vicinity of a marginal ice zone in the western Weddell Sea. Deep Sea Res. 36: 543-560

Hosie, G. W. (1991). Distribution and abundance of euphausiid larvae in the Prydz Bay region, Antarctica. Antarctic Sci. 3: 167-180

Huntley, M. E., Brinton, E. (1991). Mesoscale variation in growth and early development of Euphausia superba Dana in the western Bransfield Strait region. Deep Sea Res. 38: 1213-1240

Huntley, M. E., Nordhausen, W., Lopez, M. D. G. (1994). Elemental composition, metabolic activity and growth of Antarctic krill, Euphausia superba Dana, during winter. Mar. Ecol. Prog. Ser. 107: 23-40

Ikeda, T., Bruce, B. (1986). Metabolic activity and elemental composition of krill and other zooplankton from Prydz Bay, Antarctica, during early summer (NovemberDecember). Mar. Biol. 92: 545-555

Ikeda, T., Dixon, P. (1982). Body shrinkage as a possible overwintering mechanism of the Antarctic krill, Euphausia superba Dana. J. exp. mar. Biol. Ecol. 62: 143-151

Ikeda, T., Kirkwood, R. (1989). Metabolism and body composition of two euphausiids (Euphausia superba and E. crystallorophias) collected from under pack-ice off Enderby Land, Antarctica. Mar. Biol. 100: 301-308

Ikeda, T., Mitchell, A. W. (1982). Oxygen uptake, ammonia excretion and phosphate excretion in krill and other Antarctic zooplankton in relation to their body size and chemical composition. Mar. Biol. 71: 283-298

Kato, M., Segawa, S., Tanoue, E., Murano, M. (1982). Filtering and ingestion rates of the Antarctic krill Euphausia superba Dana. Trans. Tokyo Univ. Fish. 5: 167-175

Kawaguchi, K., Ishikawa, S., Matsuda, O. (1986). The overwintering strategy of Antarctic krill (Euphausia superba Dana) under the coastal fast ice off the Ongul Islands in Lützow-Holm Bay, Antarctica. Mem. Inst. polar Res. 44: $67-85$

Kittel, W., Stepnik, R. (1983). Distribution of Euphausia crystallorophias, E. frigida, E. triacantha and Thysanoessa macrura (Crustacea, Euphausiacea) in the southern Drake Passage and Bransfield Strait in February and March 1981. Pol. polar Res. 4: 7-19

Kittel, W., Witek, Z., Czykieta, H. (1985). Distribution of Euphausia frigida, Euphausia crystallorophias, Euphausia triacantha and Thysanoessa macrura in the southern part of Drake Passage and in the Bransfield Strait during the 1983-1984 austral summer BIOMASS-SIBEX. Pol. polar Res. 6: 133-149 
Lancraft, T. M., Hopkins, T. L., Torres, J. J., Donnelly, E. (1991). Oceanic micronektonic/macrozooplanktonic community structure and feeding in ice covered Antarctic waters during the winter (AMERIEZ 1988). Polar Biol. 11: $157-167$

Loeb, V. J., Amos, A. F., Macaulay, M. C., Wormuth, J. H. (1993). Distribution, size frequencies and maturity stages of krill, Euphausia superba, in relation to sea-ice in the northern Weddell Sea. Polar Biol. 10: 549-557

Makarov, R. R. (1979). Larval distribution and reproductive ecology of Thysanoessa macrura (Crustacea: Euphausiacea) in the Scotia Sea. Mar. Biol. 52: 377-386

Marr, J. W. S. (1962). The natural history and geography of the Antarctic krill (Euphausia superba Dana). 'Discovery' Rep. 32: 33-464

Marschall, H. P. (1988). The overwintering strategy of Antarctic krill under pack-ice of the Weddell Sea. Polar Biol. 9: 129-135

Mathew, K. J. (1988). Net avoidance behaviour among larval, juvenile, and adult euphausiids. J. mar. biol. Ass. India 30: 93-98

Mauchline, J. (1980). The biology of mysids and euphausids. Adv. mar. Biol. 18: 1-681

Mauchline, J., Fisher, L. R. (1969). The biology of euphausiids. Adv. Mar. Biol. 7: 1-454

McClatchie, S. (1988). Food-limited growth of Euphausia superba in Admiralty Bay, South Shetland Islands, Antarctica. Cont. Shelf Res. 8: 329-345

Miller, D. G. M., Barange, M., Klindt, H., Murray, A. W. A., Hampton, I., Siegel, V. (1993). Antarctic krill aggregation characteristics from acoustic observations in the southwest Atlantic Ocean. Mar. Biol. 117: 171-183

Morris, D. J., Priddle, J. (1984). Observations on the feeding and moulting of the Antarctic krill Euphausia superba Dana, in winter. Br. Antarct. Surv. Bull. 65: 57-63

Nast, F. (1982). The assessment of krill (Euphausia superba) biomass from a net sampling program. Meeresforsch. 29: $154-165$

Nicol, S., Stolp, M., Cochran, T., Geijsel, P., Marshall, J. (1992j. Growth and shrinkage of Antarctic krill Euphausia superba from the Indian Ocean sector of the Southern Ocean during summer. Mar. Ecol. Prog. Ser. 89: $175-181$

Niller, P., Illeman, J., Hu, J. H. (1990). Lagrangian drifter observations of surface circulation in the Gerlache and Bransfield Straits. Antarctic J. U.S. 25: 134-137

Nordhausen, W. (1992). Distribution and growth of larval and adult Thysanoessa macrura (Euphausiacea) in the Bransfield Strait region, Antarctica. Mar. Ecol. Prog. Ser. 83: $185-196$

Nordhausen, W. (in press). Distribution and diel vertical migration of the euphausiid Thysanoessa macrura in Gerlache Strait, Antarctica. Polar Biol.

Nordhausen, W. Huntley, M. E., Lopez, M. D. G. (1992). Carnivory by Euphausia superba during the Antarctic winter. Antarctic J. U.S. 27: 181-183

O'Brien, D. P. (1987). Direct observations of the behavior of Euphausia superba and Euphausia crystallorophias (Crustacea: Euphausiacea) under pack ice during the Antarctic spring of 1985. J. Crust. Biol. 7: 437-448

This article was submitted to the editor
Ohman, M. D. (1986). Predator-limited population growth of the copepod Pseudocalanus sp. J. Plankton Res. 8 $673-713$

Piatkowski, U. (1985). Distribution, abundance and diurnal migration of macrozooplankton in Antarctic surface waters. Meeresforsch. 30: 264-279

Pires, A. M. S. (1986). Vertical distribution of euphausiid larvae (Crustacea) in the Bransfield Strait during the 1st Brazilian Antarctic Expedition (summer 1982/83). An Acad. brasil. Cienc. 58: 43-51

Price, H. J., Boyd, K. R., Boyd C. M. (1988). Omnivorous feeding behavior of the Antarctic krill Euphausia superba. Mar. Biol. 97: 67-77

Quetin, L. B., Ross, R. M. (1991). Behavioral and physiological characteristics of the Antarctic krill, Euphausia superba. Am. Zool. 31: 49-63

Rakusa-Suszczewski, S., Stepnik, R. (1980). Three species of krill from Admiralty Bay (King George, South Shetlands) in summer 1978/79. Pol. Arch. Hydrobiol. 27: 273-284

Rustad, D. (1930). Euphausiacea, with notes on their biogeography and development. Scient. Results Norway Antarct. Exped. 5: 1-53

Segawa, S., Kato, M., Murano, M. (1982). Respiration and ammonia excretion rates of the Antarctic krill, Euphausia superba, Dana. Trans. Tokyo Univ. Fish. 5: 177-187

Siegel, V. (1987). Age and growth of Antarctic Euphausiacea (Crustacea) under natural conditions. Mar. Biol. 96: $483-495$

Siegel, V., Bergström, B., Strömberg, J. O., Schalk, P. H. (1990). Distribution, size frequencies and maturity stages of krill, Euphausia superba, in relation to sea-ice in the northern Weddell Sea. Polar Biol. 10: 549-557

Stepien, J. C. (1983). Zooplankton in the Weddell Sea, October-November 1981. Antarctic J. U.S. 17: 109-111

Stretch, J. J., Hamner, P. P., Hamner, W. M., Michel, W. C. Cook, J., Sullivan, C. W. (1988). Foraging behavior of Antarctic krill Euphausia superba on sea ice microalgae. Mar. Ecol. Prog. Ser. 44: 131-139

Tattersall, W. M. (1908). Crustacea: VII. Schizopoda. Nat. Antarct. Exped. Nat. Hist. Zool. Vol. IV, 1-42 (8 plates)

Valiela, I. (1984). Marine ecological processes. Springer-Verlag, New York

Vinogadrov, M. (1970). Vertical distribution of the oceanic zooplankton. Keter, Jerusalem (Israel Program for Scientific Translations)

Washburn, A. L., Wooster, W. S. (1981). An evaluation of Antarctic marine ecosystem research (foreword). National Academy Press, Washington, DC

Wiebe, P. H., Burt, K. H., Morton, A. W. (1976). A multiple opening/closing net and environmental sensing system for sampling zooplankton. J. mar. Res. 34: 313-326

Witek, Z., Kittel, V., Czykieta, H., Zmijevska, M. I., Presler, E. (1985). Macrozooplankton in the Southern Drake Passage and in the Bransfield Strait during BIOMASS SIBEX (December 1983-January 1984). Pol. Polar Res. 6: 95- 115

Zhou, M., Nordhausen, W., Huntley, M. E. (in press). ADCP measurements of the distribution and abundance of euphausiids near the Antarctic Peninsula in winter. Deep Sea Res.

Manuscript first received: October 28, 1993

Revised version accepted: March 17, 1994 